\title{
TAMBANG RAKYAT RENTAN KONFLIK (STUDI KASUS PERTAMBANGAN EMAS RAKYAT DI GUNONG UJEUN KABUPATEN ACEH JAYA)
}

\author{
Aminah \\ Fakultas Ilmu Sosial dan Ilmu Politik Universitas Teuku Umar \\ aminahaneukpanga@gmail.com
}

\begin{abstract}
This study aims to explain the gold miningarea in in Gunong Ujeun, Aceh jaya by using the theories of Thomas Homer-Dixon of the environmental scarcity. The data in this research was obtained through literature (library research) and field research. The research literature is done by reading textbooks, legislation, and other reading materials related to this research. While the field research conducted by interviewing informants. The results showed that the gold mining of people in Gunong Ujeun district of Aceh Jaya district is vulnerable to conflict. The conflict that occurred in the Gunong Ujeun area is a horizontal latent conflict between the immigrant community and the local community. The causes of conflict are (1) logging in Gunong Ujeun (2) more difficult to get fresh fish. (3) Environmental pollution resulting from the use of mercury and cyanide. If the cause of the conflict is not well managed then it is feared that it will have an impact on the brutal conflict or even lead to acts of violence between migrant miners and local communities surrounding the gold mining areas that are disturbed by the security and comfort.
\end{abstract}

Keywords: Conflict, environmental degradationand Peoples Mining. 


\section{PENDAHULUAN}

Sumber daya alam merupakan kekayaan yang terdapat di alam yang bertujuan untuk memberikan konstribusi yang positif terhadap kepentingan orang banyak. Bagi penduduk yang tinggal di wilayah pedesaan sumber daya alam merupakan sumber penghidupan dan cadangan penting, bukan hanya dalam kondisi kebutuhan dan kondisi kesulitan akan tetapi juga merupakan cadangan untuk masa yang akan datang.Indonesia merupakan salah satu negara yang kaya akan Sumber Daya Alam (SDA). Kekayaan sumberdaya alam ini merupakan suatu karunia Tuhan Yang Maha Esa yang diberikan kepada negara Republik Indonesia ini. Ada beberapa jenis kekayaan alam yang terdapat di negara yang sedang berkembang ini, yaitu kekayaan alam yang dapat diperbaharui (hutan, tanah, lahan subur, air, sungai, laut), dan kekayaan alam yang tidak dapat diperbaharui (minyak bumi, gas, dan bahan tambang lainnya). Menurut UndangUndang Nomor 11 Tahun 1967, bahan tambang terbagi menjadi tiga Golongan yaitu Golongan A (disebut sebagai bahan strategis), Golongn B (sebagai bahan vital) dan Golongan C (bahan tidak strategis dan tidak vital).

Dalam peraturan pemerintah Nomor 27 Tahun 1980 juga menjelaskan secara rinci bahwa jenis tambang Golongan A adalah barang yang penting bagi pertahanan, keamanan dan strategis untuk menjamin perekonomian negara dan sebagian besar hanya diizinkan untuk dimiliki oleh pemerintah. Contoh Golongan A yaitu Minyak Bumi, Uranium dan plutonium. Sedangkan bahan Golongan B adalah bahan tambang yang dapat menjamin hidup orang banyak. Contohnya adalah Emas, Perak, Besi dan tembaga. Bahan Golongan $\mathrm{C}$ adalah bahan tambang yang tidak dianggap langsung mempengaruhi hayat hidup orang banyak (Peraturan Pemerintah Nomor 27 Tahun 1980). Contoh bahan Golongan C adalah Garam, Pasir, Marmer, Batu Kapur, Tanah Liat dan Asbes.

Dibalik semua keberkahan yang telah Tuhan limpahkan ke perut bumi ini, terdapat berbagai permasalahan di daerah penghasil tambang, baik yang dihadapi oleh masyarakat penambang, masyarakat non-penambang (masyarakat yang tinggal di daerah penambangan akan tetapi tidak melakukan penambangan), pemerintah maupun Aktivis-aktivis anti tambang, yang pada akhirnya dari yang seharusnya berkah berubah menjadi musibah. Permasalahan yang paling sering dihadapi oleh daerah penghasil tambang adalah munculnya konflik, mulai dari konflik laten (konflik yang tidak muncul kepermukaan atau konflik yang tidak berujung terhadap kekerasan) hingga konflik kekerasan yang menjatuhkan korban(Aminah, 2017: 40).

Kasus pertambangan yang banyak terdapat di wilayah Indonesia sering berujung kepada konflik yang berkepanjangan di setiap wilayah. Konflik ini bisa berujung kepada konflik kekerasan atau bahkan menyebabkan kepada peperangan. Salah satunya yaitu konflik kekerasan yang berkepanjangan yang terjadi di Provinsi Aceh dan Provinsi Papua. Pemberontakan yang dilakukan oleh gerakan Hasan Tiro lebih dimotivasi oleh nasionalisme Aceh yang tumbuh sejak era kesultanan Aceh melawan penjajahan Belanda dan ketidakadilan yang dirasakan rakyat Aceh, terutama dalam hal pengelolaan sumber daya alam (Djumala, 2003: 5).Selanjutnya juga pada masa orde baru yang mengeksploitasi sumber daya alam Aceh guna menopang pembangunan nasional. Seperti eksploitasi sumber alam di Aceh dalam bentuk gas dan minyak. Eksploitasi sumber daya alam Aceh didistribusikan kembali ke Aceh hanya sampai 20\% dari pemasukan eksploitasi alam, sedangkan $70 \%$ diambil oleh pemerintah Pusat untuk pembangunan Nasional. Eksploitasi secara besar-besaran serta kurang meperhatikan masyarakat lokalpun tak terhindarkan. Pemberian hak pengelolaan kepada perusahaan-perusahaan besar atas hutan Aceh dan pemberian hak eksploitasi atas berbagai sumberdaya alam lainnya (pertambangan Minyak dan Gas) tanpa disertai alokasi yang transparan dan adil, telah menumbuhkan kekecewaan yang semakin mendalam masyarakat Aceh kepada pemerintah Pusat (M. Hamdan dan Basyar, 2006).

Fakta ini menyebabkan masyarakat Aceh berada di bawah garis kemiskinan, berpendidikan rendah, dan hancurnya identitas lokal. Tidak hanya di Aceh, hal yang sama juga terjadi di 
Papua, konflik di Papua telah dimulai sejak tahun 1949 semenjak penyatuan wilayah papua ke dalam Negara Kesatuan Republik Indonesia (NKRI). Hingga muncul kelompokperlawanan dinamakan OPM (Organisasi Papua Merdeka). OPM ini lahir semenjak tahun 1960-an. Sekitar tahun 1970-an, setelah Freeport beroperasi mendulang emas dan bahan tambang lainnya, popularitas terhadap OPM dari masyarakat Papua semakin meningkat. Kekuatan konflik di Papua dapat diredam dengan diberikannya Otonomi Khusus oleh pemerintah pusat kepada pemerintah daerah Papua (https://icssis.fies.wordpress.com)

Fakta ini menunjukkan bahwa hampir disetiap wilayah pertambangan tejadi konflik baik yang dikelola oleh pemerintah (BUMN, BUMD), pihak swasta (PT-PT) maupun oleh masyarakat secara perseorangan sangat rentan terhadap terjadinya konflik. Konflik ini dapat berupa konflik yang brutal (kekerasan) maupun konflik laten (konflik yang tidak terlihat).Hal ini seperti yang terjadi di wilayah Gunong Ujeun Kecamatan Krueng Sabee Kabupaten Aceh Jaya. Gunong Ujeun adalah salah satu lokasi tambang emas yang dikelola oleh masyarakat Kabupaten Aceh Jaya. Letaknya diapit oleh dua kecamatan yaitu Kecamatan Krueng Sabee (Gampong Panggong) dan Kecamatan Panga (Gampong Batee Meutudong). Wilayah pertambangan emas rakyat tersebut ditemukan oleh masyarakat pada tahun 2006 dan mulai diekploitasi secara besar-besaran pada tahun 2008. Wilayah pertambangan emas rakyat tersebut baru mendapatkan rekomendasi dari pihak gubernur untuk dijadikan sebagai Wilayah Pertambangan Rakyat (WPR) seluas 1.000 Ha pada tahun 2014(Aminah, 2014:37).

Bentuk konflik yang terjadi di wilayah Gunong Ujeun adalah konflik laten. Dimana dalam konflik ini tidak terlihat adanya konflik yang besar seperti tindak kekerasan dan lain sebagainya (Aminah, 2015:100). Konflik yang terjadi diwilayah Gunong Ujeun disebabkan oleh adanya masyarakat pendatang dari berbagai daerah yang juga ikut melakukan penambangan di wilayah penambangan ini. Sebagian dari masyarakat pendatang telah bergabung dengan koperasikoperasi yang telah dibentuk di dua kecamatan yaitu kecamatan Panga dan kecamatan Krueng Sabee. Namun sebagian para penambang pendatang jugaada yang tidak bergabung dengan koperasi-koperasi yang telah dibentuk dan melakukan penambangan perorangan secara tradisional di wilayah Gunong Ujeun. Hal ini akan menyebabkan timbulnya konflik diantara masyarakat pendatang dengan masyarakat lokal.

Miris memang, jika dilihat dari sumber daya alam yang besar yang terdapat di Kabupaten Aceh Jaya khususnya di bidang pertambangan emas yang memiliki nilai ekonomis yang tinggi. Seharusnya pemerintah Kabupaten Aceh Jaya mampu mengontrol praktik-praktik eksplorasi dan eksploitasi sumber daya alam secara illegal dan dapat mensejahterakan masyarakat tanpa adanya konflik yang terjadi antara pendatang dengan masyarakat lokal.Namunjika pertambangan emas rakyat ini terus dijalankan tanpa memperhitungkan lingkungan sekitar. Kondisi tersebut akan berdampak luas serta bergeser pada situasi darurat ekologi atau bahkan dapat berujung pada konflik baru, seperti environmentally induced conflict. Kerusakan hutan akibat deforestasi akan menghasilkan kerusakan Daerah Aliran Sungai (DAS). Kerusakan DAS akan sangat mempengarui siklus air tanah dan permukaan, keterancaman keanekaragaman hayati, kemampuan menyerap karbon, dan sebagainya. Kerusakan demi kerusakan lingkungan ini ketika bersinergi dengan faktor sosial, ekonomi, dan politik dapat mendorong terjadinya konflik kekerasan. Jadi, jika masyarakat terus menerus mengekploitasi sumber daya alam yang ada di Gunong Ujeun dengan merusak hutan dan penggunaan merkuri untuk membersihkan atau memisahkan antara bebatuan dengan kandungan emas secara berlebihan juga akanmenyebabkan rusaknya lingkungan yang parah terutama merusak DAS Krueng Sabee dan Panga. Terutama masyarakat lokal yang masih menggunakan air sungai Krueng Sabee dan Panga sebagai air bersih untuk penggunaan sehari-hari.

Sebelum penambangan emas dan penggunaan merkuri dilakukan oleh masyarakat penambang, air sungai Krueng Sabee dan Panga merupakan air yang sangat jernih dan bisa langsung diminum tanpa harus dimasak. Namun sejak adanya penambangan emas di Gunong 
Ujeun, air sungai Krueng Sabee yang bersih dan bening kini berubah menjadi air yang keruh dan sangat berbahaya jika dikonsumsi karena DAS Krueng Sabee tersebut telah tercemar dan banyak mengandung merkuri. Ikan-ikan yang terdapat di sungai juga tidak dapat dikonsumsi lagi.Ketidakamanan lingkungan ini dirasakan oleh kelompok masyarakat marginal. Mereka adalah kelompok yang tinggal di sekitar area wilayah pertambangan emas rakyat yang mengambil air bersih dari sungai Krueng Sabee dan Panga yang telah tercemar. Akibat limbah usaha pengelolaan pertambangan emas, sungai-sungai yang terdapat di Kecamatan Krueng Sabee dan Kecamatan Panga sudah tidak layak untuk di gunakan lagi sebagai air bersih.

Berdasarkan permasalahan diatas, tulisan ini mencoba untuk menganalisis penyebab terjadinya konflik yang terjadi diwilayah Gunong Ujeun Kabupaten Aceh Jaya. Hal ini menarik untuk dikaji karena pertambangan emas tersebut dikelola oleh masyarakat atau sering disebut sebagai wilayah pertambangan rakyat.

\section{Tinjauan Literature}

Untuk mengkaji permasalahan yang terjadi diwilayah Gunong Ujeun, penulis menggunakan Teori Kelangkaan Lingkungan (environmental scarcity) konsep dari Thomas Homer-Dixon. Homer-Dixon sangat dikenal dengan penelitian tentang hubungan lingkungan, kelangkaan dan kekerasan. Melalui penelitiannya, Homer berusaha membuat suatu gambaran yang lebih jelas kaitan antara tekanan lingkungan dan munculnya kekerasan. Dimana tekanan lingkungan yang disebut "kelangkaan lingkungan" berkontribusi terhadap kerusakan sosial dan kekerasan. Koneksi antara kelangkaan lingkungan dan kekerasan dianalisisnya secara rumit (Homer-Dixon, 1991:2).

Menurut Homer-Dixon, peperangan masa depan dan kekerasan sipil akan sering muncul karena kelangkaan sumber daya seperti air, tanah pertanian, hutan dan ikan. Negara-negara yang basis sumberdaya alamnya terancam merosot akan melakukan perlawanan yang menyebabkan munculnya konflik kekerasan (Samuel P, Hantington, 2005:117).Dalam penelitiannya, HomerDixon memfokuskan pada sumberdaya yang dapat diperbarui (renewable resources). Dalam penelitian tersebut Homer-Dixon (Homer-Dixon and Percival, 1996:12) mengajukan dua pertanyaan penelitian untuk mencari dan menjelaskan hubungan kausalitas antara kelangkaan lingkungan dan konflik sosial. Pertama, apakah kelangkaan lingkungan dapat menghasilkan kekerasan di negara berkembang?. Kedua, implikasinya, bagaimana hubungan antara keduanya?. Hubungan kausalitas antara kelangkaan lingkungan dan konflik kekerasan tidak akan menjelma menjadi konflik ketika institusi politik mampu memainkan perannya dengan baik. Jika faktor-faktor personal, institucional dan struktural ini berinteraksi dengan faktor sosial lainnya maka akan memiliki kekuatan baru untuk menimbulkan konflik kekerasan (HomerDixon, 1999; Homer-Dixon 1998; Schwartz, Deligianis \& Homer-Dixon, 2000).

Konflik kekerasan dan ketegangan sosial tidak terjadi dengan sendirinya. Konflik kekerasan muncul ketika kelangkaan lingkungan berinteraksi dengan sumber-sumber konflik yang lain yang bersumber dari sumber-sumber personal yang terdiri dari (penebangan hutan, overvising, pembuangan limbah, konservasi lahan), sumber institusional yang terdiri dari kebijakan pengelolaan hutan, AMDAL, transmigrasi, tata ruang dst) serta struktural (Gender bias, diskursus pembangunan, structural adjustment programs dst) yang bersifat suplply, demand dan struktural maka akan menimbulkan efek-efek sosial. Dari efek-efek sosial tersebut, menimbulkan konflik kekerasan atau ketegangan sosial.

Kelangkaan lingkungan (environmental scarcity) terjadi ketika kejadian-kejadian alam dan faktor-faktor fisik lainnya berinteraksi dengan faktor permintaan, penawaran, dan struktural. Akibat dari interaksi ini adalah berkurangnya produktivitas, lingkungan akibat bencana dan eksploitasi berlebihan, meningkatnya permintaan atas sumberdaya karena peningkatan konsumsi dan jumlah penduduk, dan ketidakadilan distribusi sumberdaya. Supply-induced scarcity terjadi ketika sumberdaya alam berkurang secara perlahan atau drastis akibat 
eksploitasi yang berlebihan sehingga ketersediaan sumberdaya di bumi semakin menipis. Demand-induced scarcity disebabkan oleh bertambahnya permintaan atas sumberdaya alam. Pertambahan ini disebabkan adanya peningkatan konsumsi seperti pertumbuhan penduduk, pertumbuhan di sektor industri, dan pembangunan ekonomi. Sementara, structuralinducedscarcity disebabkan oleh ketimpangan pendapatan, kekuatan ekonomi, ataupun ketidakadilan dalam mendistribusikan sumberdaya alam. Pada konteks ini, sebagian besar sumberdaya terkonsentrasi atau dikuasai oleh sekelompok kecil penduduk, sementara porsi terbesar penduduk mengalami kekurangan (Ucu Martanto, :9-10).

Dalam risetnya, Homer-Dixon kemudian mengembangkan teori kerusakan lingkungan dan kelangkaan sumber daya alam, termasuk pangan, sebagai pemicu munculnya konflik-konflik yang brutal (Homer-Dixon and Jessic Blitt, 1991: 71). Menurut Homer-Dixon biang dari seluruh permasalahan lingkungan adalah kelangkaan sumberdaya alam yang terbaharukan dan yang menjadi penyebab utama terjadinya kelangkaan sumberdaya adalah pertumbuhan penduduk yang cepat. Hal inilah yang menurut Homer-Dixon menjadi penjelas mengapa konflik atas lingkungan lebih sering terjadi di negara-negara berkembang yang pertumbuhan penduduknya yang tinggi daripada negara-negara maju yang pertumbuhan penduduknya rendah.

Homer-Dixon (1991:71) ingin menunjukkan bahwa pemenuhan kebutuhan manusia berkaitan erat dengan pergeseran kualitas sertakuantitas lingkungan. Konflik sosial akan muncul ketika tidak ada lagi keseimbanganantara jumlah yang dibutuhkan dengan yang didapatkan. Homer-Dixon menyimpulkan bahwa "Saat Kerusakan lingkungan berlanjut, besarnya gejolak sosial juga akan meningkat. Homer-Dixon juga menyatakan bahwa konflik, damai dan ketegangan yang terjadi dalam masyarakat tergantung kondisi lingkungan dan pendekatan ekonomi politik yang dilakukan di suatu negara. Pengelolaan sumber daya alam secara sentralistik rentan menyebabkan konflik, sedangkan desentralisasi mampu mengurangi resiko konflik.

Homer-Dixon menyatakan bahwa ada tiga model mengenai hubungan antara kelangkaan lingkungan (environmental scarcity) dangan faktor ekonomi-politik yang menyebabkan konflik dan ketangan sosial (lihat bagan di bawah):

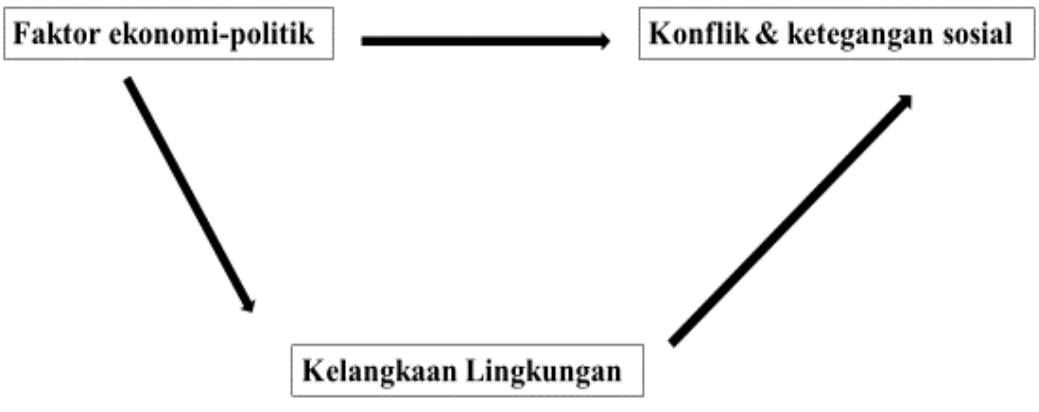

MODEL I

Gambar 1. Model I Konflik dan Ketegangan Sosial dalam Kelangkaan Lingkungan

Dari Model I dapat dilihat bahwa kelangkaan lingkungan dapat dengan sendirinya menjadi kekuatan dibelakang perubahan sosial dan ekonomi-politik yang mengatur penggunaan sumber daya. Faktor ekonomi-politik secara langsung dapat menimbulkan konflik dan ketegangan sosial dan faktor ekonomi-politik jika berinteraksi dengan kelangkaan lingkungan akan menimbulkan konflik dan ketegangan sosial. 


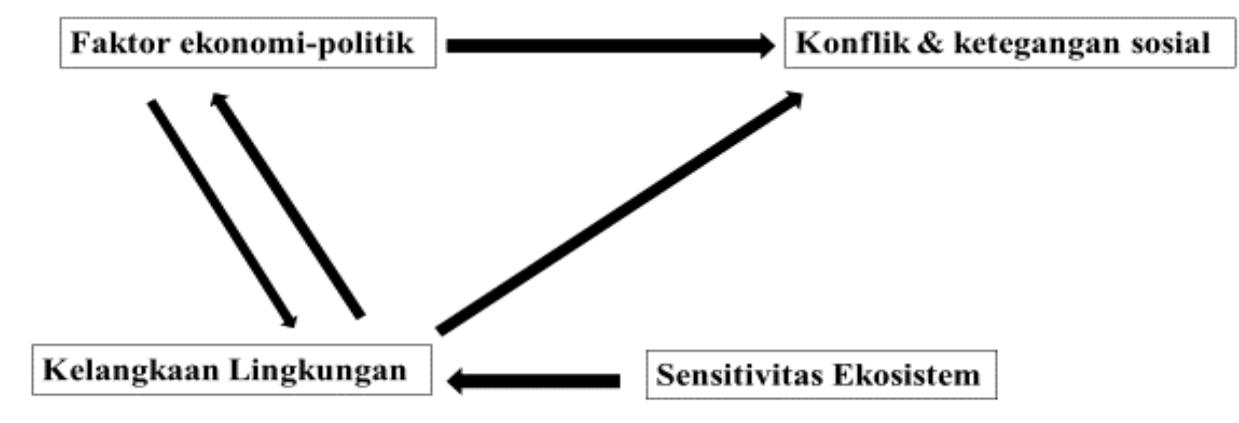

MODEL II

\section{Gambar 2. Model II Konflik dan Ketegangan Sosial dalam Kelangkaan Lingkungan}

Model II menyatakan bahwa sentivitas ekosistem sering menjadi variabel penting yang menyumbang kelangkaan lingkungan. Sensitivitas ini setidaknya merupakan faktor fisik eksternal bukan fungsi dari perilaku manusia atau perilaku lembaga sosial. Faktor ekonomipolitik secara langsung dapat menimbulkan terjadinya konflik dan ketegangan sosial. Namun jika variabel kelangkaan lingkungan dan faktor ekonomi-politik ada interaksi diantara keduanya maka akan terjadi konflik dan ketegangan sosial dalam masyarakat.

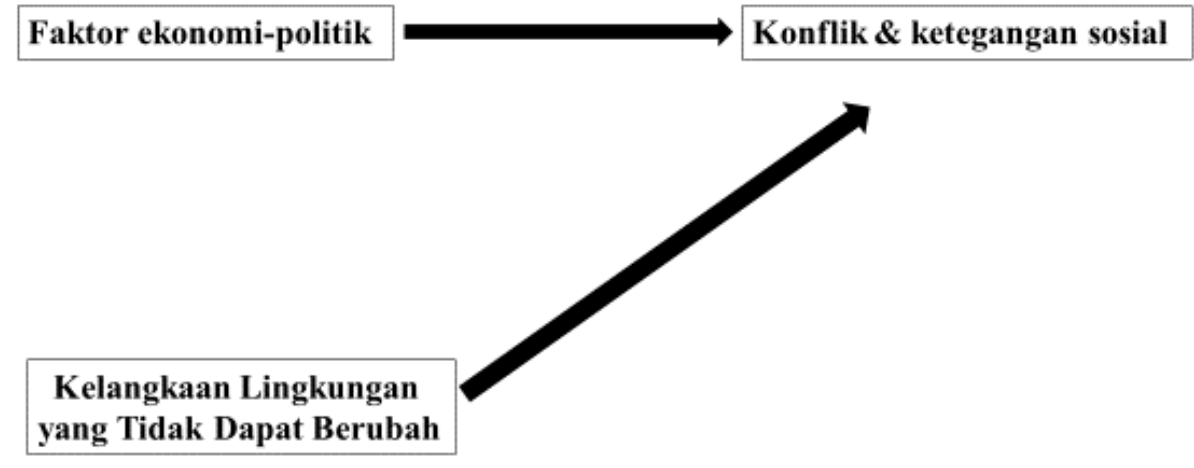

\section{MODEL III}

Gambar 3. Model III Konflik dan Ketegangan Sosial dalam Kelangkaan Lingkungan

Sedangkan, model III, dalam banyak bagian di dunia yaitu kerusakan lingkungan bersilangan dengan sebuah hambatan yang tidak dapat dirubah (a treshold of irreversibility). Terlebih, jika perubahan sosial yang mencerahkan menghilangkan sebab-sebab budaya, ekonomi dan politik, maka ia akan menjadi beban yang menyusahkan masyarakat. Dari hal ini dapat dilihat bahwa faktor ekonomi-politik dan kelangkaan lingkungan yang tidak dapat berubah secara langsung dapat menimbulkan konflik dan ketegangan sosial.

Berdasarkan Tipenya, konflik terbagi atas 4 tipe yaitu sebagai berikut:

Konflik Laten: Konflik laten merupakan suatu konflik yang bersifat tersembunyi, karenanya perlu diangkat kepermukaan sehingga dapat ditangani secara efektif. Jika konflik terus-menerus seperti ini dikhawatirkan akan dapat menimbulkan terjadinya konflik kekerasan.

Konflik terbuka:Konflik terbuka adalah konflik yang berakar dalam dan sangat nyata serta memerlukan berbagai tindakan untuk mengatasi akar penyebabnya dan berbagai efeknya. 
Konflik dipermukaan: Konflik dipermukaan adalah konflik yang memiliki akar yang dangkal atau tidak berakar dan terjadi hanya karena kesalahpahaman saja mengenai sasaran yang dapat diatasi dengan mengintesifkan komunikasi diantara kedua belah pihak yang sedang berkonflik.

Konflik yang mengakar: Konflik yang mengakaradalah konflik yang berasal dari dalam negara yang mengkombinasikan dua elemen kuat.

\section{METODE PENELITIAN}

Metode penelitian yang digunakan dalam penelitian yaitu metode penelitian kualitatif dengan pendekatan studi kasus. Adapun yang menjadi lokasi penelitian ini adalah Gunong Ujeun Kecamatan Krueng Sabee Kabupaten Aceh Jaya, Provinsi Aceh, dengan pertimbangan bahwa, lokasi tersebut merupakan salah satu wilayah pertambangan emasrakyat yang menimbulkan konflik antara masyarakat pendatang dengan masyarakat lokal.

Teknik pengumpulan data dilakukan melalui kepustakaan dan lapangan. Kepustakaan dengan membaca buku teks dan bahan bacaan lainnya yang berkaitan dengan tema penelitian sedangkan lapangan dengan mewawancarai para informan yang menjadi sumber informasi bagi penulis untuk menganalisis dengan menggunakan teori yang digunakan. Sedangkan teknik analisis data yaitu Proses analisis data dimulai dengan menelaah seluruh data yang tersedia dari berbagai sumber, setelah menelaah langkah berikutnya yaitu mereduksi data dengan melakukan abstraksi atau membuat rangkuman inti. Tahap ketiga yaitu menyusun data-data tersebut dalam satuan-satuan dan tahap akhir dari analisis data ialah melakukan pemeriksaan keabsahan data (Moleong, 2002: 247).

\section{HASIL DAN PEMBAHASAN}

Dari hasil penelitian dilapangan mengungkapkan dalam proses penambangan emas rakyat di wilayah Gunong Ujeun Kabupaten Aceh Jaya telah terjadi konflik bersifat laten. Konflik tersebut terjadi antara masyarakat pendatang dengan masyarakat lokal. Hingga saat ini, wilayah pertambangan emas rakyat di Gunong Ujeun masih dikatagorikan sebagai PETI (Pertambangan Emas Tanpa Izin). Namun, pengekploitasian tambang emas rakyat semakin lama semakin marak dilakukan. Banyak masyarakat yang datang dari berbagai daerah ke lokasi Gunong Ujeun untuk bekerja sebagai penambang terutama dari wilayah pulau Jawa (Bogor) dan kabupaten/kota lainnya baik yang bergabung dengan koperasi yang ada di kecamatan Panga dan Kecamatan Krueng Sabee maupun bekerja secara individu (tidak bergabung dengan Koperasi).Namun meskipun Kabupaten Aceh Jaya memiliki kekayaan alam berupa tambang emas namun hingga saat ini pemerintah kabupaten Aceh Jaya belum menerima pendapatan asli daerah dari hasil tambang emas tersebut (Aminah, 2016:137).

Sumber daya alam dapat dikategorikan menjadi dua yaitu sumberdaya alam yang dapat diperbaharui (renewable resources) dan sumberdaya alam yang tidak dapat diperbaharui (nonrenewable resources). Dari kedua kategori ini masing-masing memiliki potensi serta konsekuensi jika berada dalam kondisi kelangkaan.Studi terkait konflik kekerasan terkait dengan kelangkaan sumberdaya alam yang tidak dapat diperbaharui (non-renewable resources) telah banyak dikaji oleh para peneliti sebelumnya dan menjelaskan bahwa ada hubungan atau keterkaitan antara sumberdaya alam yang tidak dapat diperbaharui dengan konflik kekerasan yang terjadi disuatu daerah. Ha ini desebabkan karena adanya perebutan pada saat melakukan penambangan dan juga disebabkan karena sumberdaya alam yang tidak dapat diperbaharui. Sehingga konflik kekerasan dan konflik sosial didalam wilayah tersebut tidak dapat dihindarkan.

Namun disisi lain, kita sering mengabaikan sumberdaya alam yang dapat diperbaharui. Padahal sumberdaya alam yang dapat diperbaharui juga merupakan salah satu faktor yang sangat penting dalam hubungan antara kelangkaan lingkungan dan konflik sosial. Bahkan dapat menyebabkan terjadinya konflik kekerasan. Setiap konflik yang pernah terjadi dimanapun selalu 
ada penyebab atau faktor-faktor yang memicu sehingga konflik tersebut mencuat bahkan mengundang konflik yang lebih besar didalam lingkungan masyarakat atau pihak yang saling bertikai.Adapun yang menjadi penyebab atau faktor-faktor konflik yang terjadidi wilayah pertambangan emas rakyat Gunong Ujeun Aceh Jaya adalah sebagai berikut:

\section{a. Penebangan hutan di Gunong Ujeun}

Jika dikaitkan dengan yang terjadi di wilayah Gunong Ujeun bahwa sejak pertambangan emas rakyat di wilayah Gunong Ujeun terbentuk, penebangan hutan di Gunong Ujeun yang dulunya merupakan wilayah hutan produksi dilakukan secara besar-besaran oleh masyarakat penambang emas rakyat. Hutan yang dulunya lebat dan jarang dilewati oleh masyarakat berubah menjadi hutan yang gundul dan penebangan liar di wilayah hutan ini.Sejak penambangan tersebut mendapat rekomendasi dari Gubernur Aceh pada tahun 2010 pada masa kepemimpinan Irwandi Yusuf, proses eksploitasi pertambangan emas rakyat ini semakin marak dilakukan. Akibat penebangan hutan liar ini, banjir bandang semakin sering terjadi di wilayah Kabupaten Aceh Jaya. Meskipun beberapa informan menyatakan bahwa banjir yang terjadi di Kabupaten Aceh Jaya bukan karena adanya penambangan emas rakyat di Gunong Ujeun akan tetapi karena faktor alam (hujan yang terus menerus terjadi). Namun beberapa informan meyakini bahwa banjir yang terjadi di Kabupaten Aceh Jaya merupakan kiriman dari para penambang yang selama ini tidak mengindahkan lingkungan, sehingga banjir yang melanda Aceh Jaya akhir-akhir ini lebih sering terjadi, bahkan dalam satu tahun banjir di Aceh Jaya terjadi sampai 4-5 kali.

\section{b. Sulit mendapatkan Ikan yang segar}

Sejak penambangan emas rakyat di Gunong Ujeun dilakukan, masyarakat kabupaten Aceh Jaya khususnya di Kecamatan Panga dan Kecamatan Krueng Sabee juga sulit untuk mendapatkan ikan-ikan yang segar untuk dikonsumsi. Hal ini seperti yang dirasakan oleh salah satu masyarakat bernama Siti (bukan nama sebenarnya) yang melahirkan bayi cacat yang divonis oleh dokter dan tim penelitian bahwa anak yang dilahirkannya cacat akibat dampak dari Merkuri. Selama mengandung, Siti tinggal di Kecamatan Krueng Sabee dan sering mengkonsumsi kerang yang diambil dari aliran sungai Krueng Sabee, selain itu Siti juga mengambil air dari sungai tersebut untuk penggunaan sehari-harinya. Akibatnya dokter dan para peneliti menyatakan bahwa air sungai Krueng Sabee telah tercemar merkuri dan tidak dapat digunakan lagi untuk mandi, masak dan lain sebagainya. Hal ini menimbulkan konflik laten antara keluarga Siti dengan pihak penambangan emas di Gunong Ujeun.

\section{c. Pencemaran Lingkungan}

Pencemaran lingkungan yang terjadi sejak hadirnya penambangan emas di Wilayah Gunong Ujeun semakin meresahkan masyarakat. banyak sumur masyarakat sudah tidak dapat difungsikan kembali karena sumurnya dinyatakan mengandung merkuri. Hal Ini disebabkan karena tetangganyamelakukan penggilingan bebatuan emas di rumahnya.Dalam melakukan pengolahan bebatuan emas dibutuhkan cairan kimia yang berbahaya bagi kesehatan yaitu sianida dan merkuri.Dengan penggunaan sianida dan merkuri tersebut pengolahan emas akan lebih mudah untuk memisahkan antara bebatuan dengan kandungan emas.Akibat dari penggunaan sianida dan merkuri ini, masyarakat sekitar penambangan emas rakyat atau yang tinggal berdekatan dengan gelondongan emas merasa waspada dan takut untuk menggunakan air bersih baik dari sungai maupun air sumur.Sekitar tahun 2012 pihak rumah Sakit Teuku Umar Aceh Jaya pernah mengambil air 20 sumur yang terdapat di Kecamatan Panga dan Kecamatan Krueng Sabee untuk diuji di laboratorium.Berdasarkan hasil uji laboratorium pihak rumah sakit menjelaskan bahwa dari beberapa sumur tersebut yang telah diambil sampelnya bahwa 70\% air sumur masyarakat telah tercemar oleh sianida dan merkuri. Hal ini menyebabkan Masyarakat akan semakin sulit untuk mendapatkan air bersih dan untuk minum serta mandi sebagian masyarakat yang sumurnya telah tercemar harus membeli air.Hal ini tentu akan melahirkan kembali gejolak-gejolak sosial didalam 
masyarakat. Terutama masyarakat yang tidak melakukan penambangan emas namun air sumur mereka telah tercemar. Konflik ini sering terjadi pada masa penambangan emas rakyat di Gunong Ujeun marak dilakukan yaitu pada tahun 2006-2012 oleh masyarakat yang datang dari berbagai daerah.

Pencemaran lingkungan tersebut dapat berlangsung dalam kurun waktu yang lama. Apabila hal ini terus dibiarkan oleh pihak pemerintah terkait dan tidak dicegah maka kerusakan lingkungan akan semakin parah, terutama daerah aliran sungai Krueng Sabee akan menjadi rusak sehingga menyebabkan degradasi lingkungan yang tidak sepadan dengan nilai ekonomi yang dihasilkan dari Gunong Ujeun yaitu emas. Selain itu, pertambangan rakyat yang tidak memperhatikan aspek lingkungan seperti yang terjadi di Gunong Ujeun akan menyebabkan terancamnya daerah sekitar pertambangan tersebut dari bahaya erosi dan tanah longsor sebagai hilangnya vegetasi penutup tanah.

Sejak proses eksploitasi pertambangan emas rakyat di Gunong Ujeun mulai dilakukan, telah banyak hal yang berubah mulai dari tatanan hutan hingga aliran sungai Krueng Sabee. Rusaknya hutan tersebut akan berdampak kepada sumberdaya alam lainnya seperti siklus tanah sudah tidak subur lagi, perubahan warna air dan kualitas air, serta kerusakan terhadap ikan-ikan yang berada disungai akan mati serta beracun akibat limbah merkuri yang dialirkan ke sungai Krueng Sabee Aceh Jaya.Dari beberapa penyebab konflik diatas, jika saling berinteraksi antara satu dengan lainnya akan menyebabkan kelangkaan lingkungan yang nantinya juga akan berujung pada tindak kekerasan (konflik kekerasan). Untuk menghindari dampak negatif dari kelangkaan lingkungan ini, pemerintah kabupaten Aceh Jaya beserta seluruh jajarannya mulai dari pihak dinas-dinas terkait hingga pihak kepolisian harus lebih memperhatikan aspek lingkungan dan masyarakat sekitar wilayah pertambangan emas rakyat di Gunong Ujeun. Hal ini untuk menghindari terjadinya konflik sosial yang diyakini akan menimbulkan konflik sosial didalam masyarakat.

\section{SIMPULAN}

Berdasarkan pembahasan dan analisis data diatas menunjukkan bahwa dalam proses eksploitasi pertambangan emas rakyat di Gunong Ujeun telah memunculkan konflik sosial. Konflik sosial yang terjadi adalah konflik yang bersifat laten secara horizontal yaitu antara masyarakat penambang pendatang dengan masyarakat lokal. Dalam konflik ini telah memperlihatkan bahwa adanya hubungan antara kelangkaan lingkungan yang menyebabkan terjadinya penebangan hutan di Gunong Ujeun, masyarakat sulit mendapatkan ikan yang segar serta terjadinya pencemaran lingkungan akibat dari penggunaan mercuri dan sianida.

\section{REFERENSI}

Aminah. 2014. Kebijakan Pemerintah Aceh Jaya dalam Pengelolaan Tambang Emas Rakyat (Studi Kasus Pertambangan Emas di Kecamatan Krueng Sabee).Skripsi.Fakultas Ilmu Sosial dan Ilmu Politik Universitas Syiah Kuala, Banda Aceh.

Aminah, 2015.Politik Pertambangan Emas Rakyat (Studi Kasus Konflik Pertambangan Emas Di Gunong Ujeun Aceh Jaya).Tesis. Fakultas Ilmu Sosial dan Ilmu Politik Universitas Airlangga, Surabaya.

Aminah, 2016. Kebijakan Pemerintah Kabupaten Aceh Jaya dalam Pengelolaan Tambang Emas Rakyat Di Gunong Ujeun. Jurnal Public Policy.2 (2): 137

Aminah, 2017. Tambang Rakyat, Berkah atau Musibah? (Studi Tentang Tambang Emas Rakyat

Di Gunong Ujeun Kabupaten Aceh Jaya). Jurnal Public Policy. 3 (1): 41

Basyar, M.H dkk. 2006. Aceh Baru: Tantangan Perdamaian dan Reintegrasi, Yogyakarta: Pusat Penelitian Politik-LIPI. 
Djumala, Darmasjah. 2013. Shoft Power Untuk Aceh: Resolusi Konflik dan Politik Desentralisasi, Jakarta: PT. Gramedia Pustaka Utama.

Hantington, Samuel P. 2005. Amerika dan Dunia: Memperdebatkan Bentuk Baru Politik Internasional, Jakarta: Yayasan Obor Indonesia.

Homer-Dixon, T. F dan Jessic Blitt, 1991, Evidence: Links Among Environment, Population and Scarcity, New York: Rowman and Littlefield.

Homer-Dixon, T. 1991. On the Threshold: Environmental Changes as Causes of Acute Conflict. JournalInternational Security.16 (2) (Fall).

Homer-Dixon, T. 1999. Environment, Scarcity. Violence. Princeton University Press: New Jersey.

Martanto, Ucu, "Perubahan Lingkungan dan Konflik Kekerasan: Membaca Papua Melalui Pendekatan Environmental Security",Laporan Penelitian,Yogyakarta: Universitas Gajah Mada.

Martanto, Ucu. 2009, Paper Seminar International, "Center for Peace and Conflict Resolution", 12 Novermber 2009, Syiah Kuala University, Banda Aceh, Indonesia. Hal: 8.

Moleong Y, 2002, Metodologi Penelitian Kualitatif Edisi Revisi, Bandung; PT. Remaja Rosdakarya.

Nomensen. 2013. Mereduksi Konflik Vertikal dan Horizontal Di Papua. https://icssis.fies.wordpress.com/2013-02-14.pdf. Diakses tanggal 17 Juli 2017.

\section{Peraturan Perundang-Undangan}

Undang-Undang Nomor 11 Tahun 1967 Tentang ketentuan-ketentuan pokok pertambangan

Peraturan Pemerintah Nomor 27 Tahun 1980 Tentang Penggolongan Bahan-Bahan Galian 